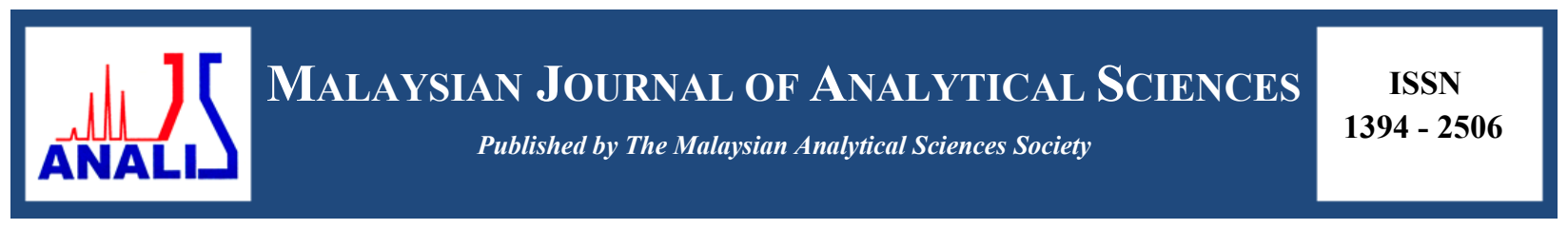

\title{
THE COMMON PITFALL OF USING ENRICHMENT FACTOR IN ASSESSING SOIL HEAVY METAL POLLUTION
}

\author{
(Kepincangan Penggunaan Faktor Pengkayaan dalam Menilai Pencemaran Logam Berat \\ di dalam Tanah)
}

Seng-Chee Poh* and Norhayati Mohd Tahir

School of Marine and Environmental Sciences, Universiti Malaysia Terengganu, 21030 Kuala Terengganu, Terengganu, Malaysia

*Corresponding author: poh@umt.edu.my

Received: 5 November 2016; Accepted: 8 December 2016

\begin{abstract}
A soil pollution assessment of heavy metal $\mathrm{Zn}, \mathrm{Cu}, \mathrm{Cr}, \mathrm{Cd}, \mathrm{Ni}$ and $\mathrm{Pb}$ was carried out in Kuala Terengganu, Malaysia. A total of 245 surface soil samples were sampled and have been subjected to a total digestion and analyzed by inductive couple plasmaoptical emission spectrometry (ICP-OES). The contamination of the soils was assessed on the basis of enrichment factors (EFs). Large discrepancies in results of enrichment factor associated with the choices of reference elements in the EFs' calculation have been observed. Our study show that the choice of four commonly-used reference elements ( $\mathrm{Al}, \mathrm{Fe}, \mathrm{Ca}$ and $\mathrm{Mn})$ in enrichment calculation could easily alter the enrichment factor values of element of interest by more than 4-folds although the results were supposed to be similar regardless of which reference elements being used. This could lead to serious misinterpretation of soil quality assessment result.
\end{abstract}

Keywords: soil quality assessment, Malaysia soil, elemental analysis, acid digestion

\begin{abstract}
Abstrak
Satu penilaian pencemaran logam berat $\mathrm{Zn}, \mathrm{Cu}, \mathrm{Cr}, \mathrm{Cd}$, Ni dan $\mathrm{Pb}$ dalam tanah telah dijalankan di Kuala Terengganu, Malaysia. Sebanyak 245 sampel tanah telah diambil, diproses berdasarkan kaedah penghadaman asid dan kepekatan logam berat telah dianalisa dengan menggunakan spektrofotometer pancaran plasma gandingan aruhan (ICP-OES). Pencemaran tanah telah dinilai menggunakan pendekatan faktor pengkayaan. Kajian ini menunjukan nilai-nilai faktor pengkayaan boleh berbeza dengan ketara apabila pengiraan faktor pengkayaan dirujukkan kepada elemen rujukan yang berbeza. Kajian kami mendapati nilai-nilai faktor pengkayaan boleh berbeza sebanyak empat kali ganda apabila pengiraan faktor pengkayaan merujuk kepada $\mathrm{Al}, \mathrm{Fe}, \mathrm{Ca}$ dan $\mathrm{Mn}$ dan perbezaan nilai-nilai faktor pengkayaan boleh membawa wujudnya kesilapan dalam mentafsir kualiti tanah yang dikaji.
\end{abstract}

Kata kunci: kajian kualiti tanah, tanah Malaysia, analisa unsur, penghadaman asid

\section{Introduction}

Heavy metals like $\mathrm{Cd}, \mathrm{Pb}, \mathrm{Zn}, \mathrm{Cu}, \mathrm{Cr}$ and $\mathrm{Ni}$ in soil have received wide attention due to their potential toxic impact on the environment if present in excessive concentrations. It is critically important to carry out soil quality monitoring program on a regular basis, particularly in urban watershed to support sustainable planning and development for better livelihood. There are three common approaches of assessing soil quality: (1) take measurements periodically over the time to monitor changes or trends in soil quality; (2) compare measured values to a standard or reference soil condition (i.e. Netherlands' Dutch Target, Australia's Soil Investigation Level, 
USEPA Ecological Screening Levels, British Soil Guideline and Japanese Environmental Quality Standards). The former method is commonly used by stakeholders to identify areas where problems occur, to identify areas of special interest, or to compare fields under different management systems over time and latter generally adopted by law enforcement authorities for soil pollution control and mitigation. Finally, the third approach is based on calculation of enrichment factors (EFs) to evaluate anthropogenic influences on soil quality.

Enrichment factor is an index used as a proxy to assess the heavy metals contamination level in soil by estimating the differential of heavy metal concentrations against uncontaminated background or reference levels [1,2]. An enrichment factor can be defined as in equation 1 :

$$
\mathrm{EF}_{i}=\frac{(\mathrm{y} / \mathrm{x})_{\text {sample }}}{(\mathrm{y} / \mathrm{x})_{\text {background }}}
$$

where, $y$ is concentration of target metal, $x$ is concentration of reference element or normalizer in soil and in background or baseline reference material. In soil quality study, the interpretation of enrichment factor is based on the deviation of the ratio between a metal of interest and a reference element that exhibit conservative and immobile behavior in environment in a sample to the equivalent ratio in a reference material from unity $(\mathrm{Efs}=1)$. Enrichment factor equal to one is generally taken to mean that there has been no net gain or loss of a metal in the sampled soil respective to the reference material. Enrichment factor ratio should increase (Efs $>1$ ) if there has been a net gain of metal concentration due to extra input (e.g. anthropogenic sources), and a net loss of metal concentration in the system (e.g. due to weathering, biological assimilation) should decrease the ratio value $(\mathrm{Efs}<1)$.

Enrichment factor is practice widely in environmental studies. Nevertheless, the assumption of enrichment factor as pollution detection tool inherits many theoretical shortcomings [3,4]. The work done by Reimann and de Caritat $[3,4]$ concluded that EFs calculation is strongly influenced by the natural variable composition of the reference material, biogeochemical processes and physico-chemical alteration of elements in crust materials. The authors regarded using EFs to interpret pollution event in any environmental sudies as doubtful. The primary objective of this study is to determine the metal concentrations in soil of Kuala Terengganu. Fortuitously, this study will allow to test the reliability of enrichment factor as a pollution proxy for soil quality assessment.

\section{Soil sampling}

\section{Materials and Methods}

The soil quality assessment was carried out in Kuala Terengganu district, Malaysia $\left(5.33^{\circ} \mathrm{N}, 103.1^{\circ} \mathrm{E}\right.$, Figure 1). Sampling of soil had been accomplished on 245 cells of $1 \mathrm{~km} \mathrm{x} 1 \mathrm{~km}$ square grid using the topographic maps. About $1 \mathrm{~kg}$ of soil sample was collected from the first $10-15 \mathrm{~cm}$ of the upper soil horizon using a plastic spade at each grid. The collected samples were air-dried, ground, and passed through sieve of a $0.6 \mathrm{~mm}$ mesh size for subsequent acid digestion.

\section{Soil digestion and chemical analysis}

All soil digestion and element analysis was performed in analytical chemistry laboratory of Universiti Malaysia Terengganu (UMT). All apparatus used in this experiment were acid-cleaned with $10 \% \mathrm{HNO}_{3}$. The soil digestion procedure for heavy metal analysis was carried out using USEPA method 3052. In general, an acid mixture of $\mathrm{HNO}_{3}: \mathrm{HCl}: \mathrm{HF}(9: 4: 1) \mathrm{ml}$ ratio was added to $0.5 \mathrm{~g}$ of soil sample inside a Teflon vessel. Later, digestions of soils were performed in a microwave-heated oven (Ethos Plus Milestone, USA) at $210{ }^{\circ} \mathrm{C}$ for 20 minutes. After digestion, small amount of saturated $\mathrm{H}_{3} \mathrm{BO}_{3}$ acid was added into solution to neutralize remaining active $\mathrm{HF}$ in solution. The digested solution then makes up to $25 \mathrm{ml}$ of final volume with ultrapure deionized water. A complete digested soil sample will normally yield a clear solution. Quality control and quality assurance also carried out by using two standard reference materials SRM-2709 and SRM-2711 obtained from the National Institute of Standards and Technology (NIST, USA). The SRMs were subjected to similar sample treatment procedures as described above. All samples and SRMs were analyzed for $\mathrm{Al}, \mathrm{Fe}, \mathrm{Mn}, \mathrm{Ca}, \mathrm{Zn}, \mathrm{Cu}, \mathrm{Cr}, \mathrm{Cd}, \mathrm{Ni}$ and $\mathrm{Pb}$ by inductive couple plasma optical emission spectrometer (Varian Vista Pro, Australia). SRMs recovery result shows that the analytical accuracy for all measured metals in SRM $(\mathrm{n}=12)$ was within $5-15 \%$ error for all metals, expect for Cr which was $10-25 \%$ error. 


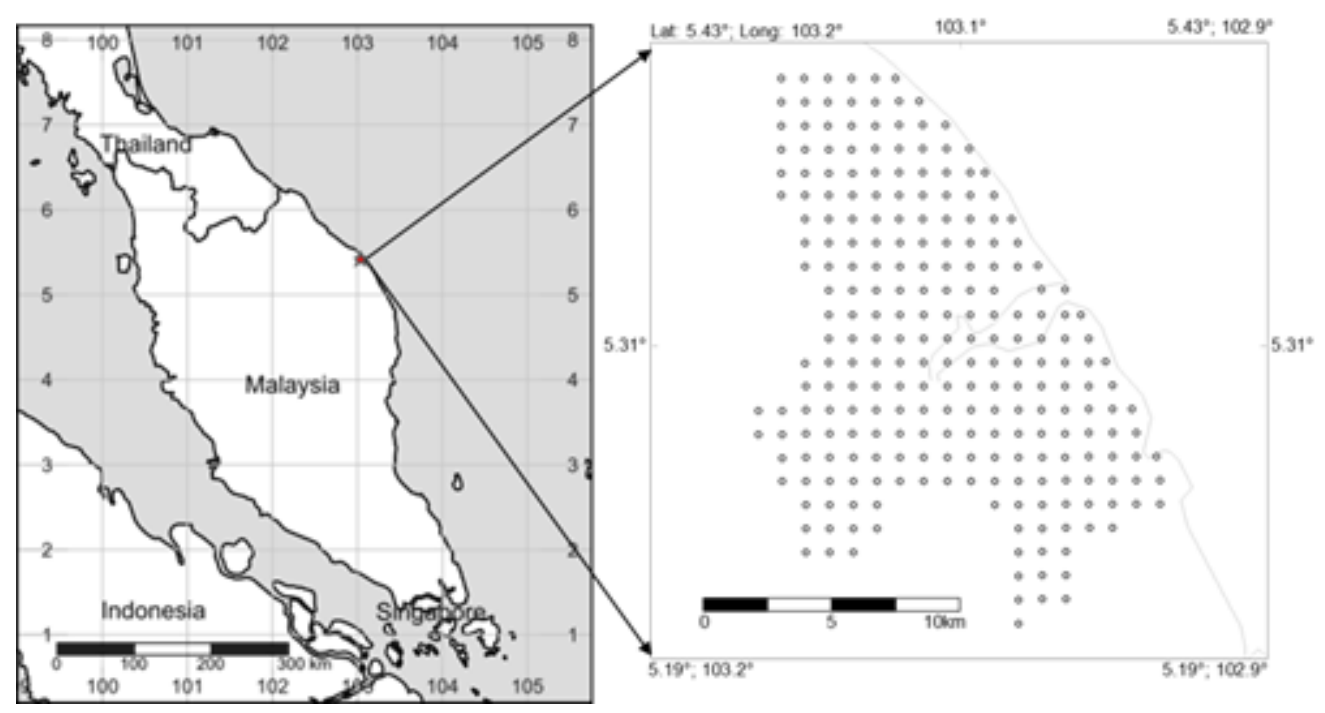

Figure 1. The sampling site in Kuala Terengganu district

\section{Enrichment factor calculation and geochemical mapping}

The calculation of a normalized enrichment factor for a given metal for this study is represented by equation 1 . Where, $\mathrm{EF}_{i}$ is the enrichment factor of target metal $i,(\mathrm{y} / \mathrm{x})_{\text {sample }}$ is the target metal to reference (conservative) element' ratio in the samples of interest; while $(\mathrm{y} / \mathrm{x})_{\text {background }}$ is the target metal to reference metal ratio in world soil baseline reference taken from Ure and Berrow [5].

\section{Heavy metals concentration in Kuala Terengganu soil}

\section{Results and Discussion}

The concentration range of metals in Kuala Terengganu soils and their mean values are given in Table 1. The mean concentration values of all metals, except $\mathrm{Cd}$ in surface soil of Kuala Terengganu were lower than those reported in worldwide average values [5].

Level of $\mathrm{Al}(0.45 \%), \mathrm{Ca}(0.14 \%), \mathrm{Mn}(82.9 \mathrm{mg} / \mathrm{kg})$ in the soil samples studied was found much lower (10 fold) than those reported by Ure and Berrow [5] for world average values $6.65 \%, 1.96 \%$ and $760 \mathrm{mg} / \mathrm{kg}$, respectively. The studied soil samples were relatively poor in $\mathrm{Fe}, \mathrm{Cu}, \mathrm{Cr}, \mathrm{Zn}$ and $\mathrm{Ni}$. The mean values of these metals were lower than those reported by Zarcinas et al. [7] for Malaysian agricultural soils (Table 2) and for world average value [5]. Level of $\mathrm{Pb}(23.6 \mathrm{mg} / \mathrm{kg})$ detected in the soil samples were similar to those found in Zarcinas et al. [7] $(26.4 \mathrm{mg} / \mathrm{kg})$ and worldwide average value $(29.2 \mathrm{mg} / \mathrm{kg})$. Conversely, the content of $\mathrm{Cd}$ in studied soil ranged between 0.38 and $6.78 \mathrm{mg} / \mathrm{kg}$ with the median concentration of $1.28 \mathrm{mg} / \mathrm{kg}$ and was found to be two times greater than the mean concentration of world average $(0.62 \mathrm{mg} / \mathrm{kg})$.

The Baging, Rhutapai, Rusila and Rudua soil series associated to BRIS (Beach Ridges Interspersed with Swales) were reported as dominant soils in these areas [6]. The low heavy metal concentrations in Kuala Terengganu soil indicates the sampled soils are mainly originated from highly weathered BRIS soils. The decreasing order of concentration on the different metals $\mathrm{Fe}>\mathrm{Al}>\mathrm{Ca}>\mathrm{Mn}>\mathrm{Zn}>\mathrm{Pb}>\mathrm{Cr}>\mathrm{Cu}>\mathrm{Ni}>\mathrm{Cd}$ reflects their abundance in BRIS soil are associated with low cation exchange capacity, low organic matter content, and excessively-drained sandy soil properties promote leaching losses. 
Poh \& Mohd Tahir: THE COMMON PITFALL OF USING ENRICHMENT FACTOR IN ASSESSING SOIL HEAVY METAL POLLUTION

Table 1. The range, median, mean of selected metals in surface soil of Kuala Terengganu (in $\mathrm{mg} \mathrm{kg}^{-1}, \mathrm{n}=245$ )

\begin{tabular}{lcccc}
\hline Metal & Range & Median & Mean & Worldwide Average [5] \\
\hline $\mathrm{Al}^{*}$ & $0.14-1.44$ & 0.42 & 0.45 & 6.65 \\
$\mathrm{Fe}^{*}$ & $0.22-7.70$ & 1.54 & 1.57 & 3.20 \\
$\mathrm{Mn}$ & $2.53-356$ & 51.3 & 82.9 & 760 \\
$\mathrm{Ca}{ }^{*}$ & $0.01-1.17$ & 0.08 & 0.14 & 1.96 \\
$\mathrm{Zn}$ & $4.61-204$ & 31.4 & 38.3 & 59.8 \\
$\mathrm{Cu}$ & $0.82-148$ & 9.39 & 10.9 & 25.8 \\
$\mathrm{Cr}$ & $3.05-50.1$ & 21.6 & 20.5 & 84.0 \\
$\mathrm{Cd}$ & $0.38-6.78$ & 1.21 & 1.28 & 0.62 \\
$\mathrm{Ni}$ & $1.91-16.7$ & 7.18 & 7.02 & 33.7 \\
$\mathrm{~Pb}$ & $2.54-160$ & 21.9 & 23.6 & 29.2 \\
\hline
\end{tabular}

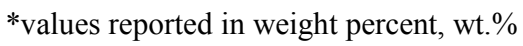

\section{Soil pollution assessment of heavy metals using enrichment factor}

To allow quantitative comparisons between degrees of metals enrichment in the soil pollution assessment, Sutherland [8] and Loska et al [9] had distinguished five contamination categories of the enrichment factor. An EF $<2$ is deficiency of minimal enrichment, suggestive of no or minimal pollution; EF 2 - 5 is moderate enrichment; EF 5 - 20 is significant enrichment; EF 20 - 40 is very high enrichment and EF > 40 is extremely high enrichment, indicating an extreme pollution signal. Several elements are utilized as normalizer in enrichment factor, in particular element that have been associated with rock-forming minerals (see summary in Table 2).

Table 2. Selection and justification of reference element for enrichment factor calculation in relation to assess anthropogenic impact

\begin{tabular}{lll}
\hline Normalizer & Justification & Reference \\
\hline $\mathrm{Al}$ & $\begin{array}{l}\text { Al has no significant anthropogenic input compared to the large } \\
\text { of geogenic element; Ion potential of Al is close to target } \\
\text { elements, reduce variation in comparison }\end{array}$ & {$[10]$} \\
$\mathrm{Mn}$ & $\begin{array}{l}\text { Mn is one of largest components of soil } \\
\mathrm{Fe}\end{array}$ & $\begin{array}{l}\text { Fe is abundant in soils; considered to be free from anthropogenic } \\
\text { contribution }\end{array}$ \\
$\mathrm{Ca}$ is one of the main components of the Earth's Crust, \\
$\mathrm{Ca}$
\end{tabular}

The scatter plot in Figure 2 illustrates a comparison study of selected elements EF against different normalizers (Fe, $\mathrm{Al}, \mathrm{Ca}$ and $\mathrm{Mn}$ ) and the obtained results showed that $\mathrm{EF}$ values of metal were different corresponding to the 
normalizers used. For better interpretation, four different colour lines representing the contamination categories scale suggested by Sutherland [8] and Loska et al. [9] were plotted (Figure 2). For example, if a sample fall within green and yellow line, then the sample was classified as being moderate enriched $(\mathrm{EF}=2-5)$. If it falls between the yellow and orange line, then the sample was classified as significant enrichment $(E F=5-20)$. If a sample surpassed the orange line but was within the red line, then the sample was classified as being very highly enriched $(\mathrm{EF}=20$ 40). Samples with the enrichment factor greater than 40 that were found to have surpassed the red line were classified as samples with severe pollution. If samples fall below green line $(\mathrm{EF}<2)$, then samples were classified as depletion to minimal enrichment suggestive of no or minimal pollution.

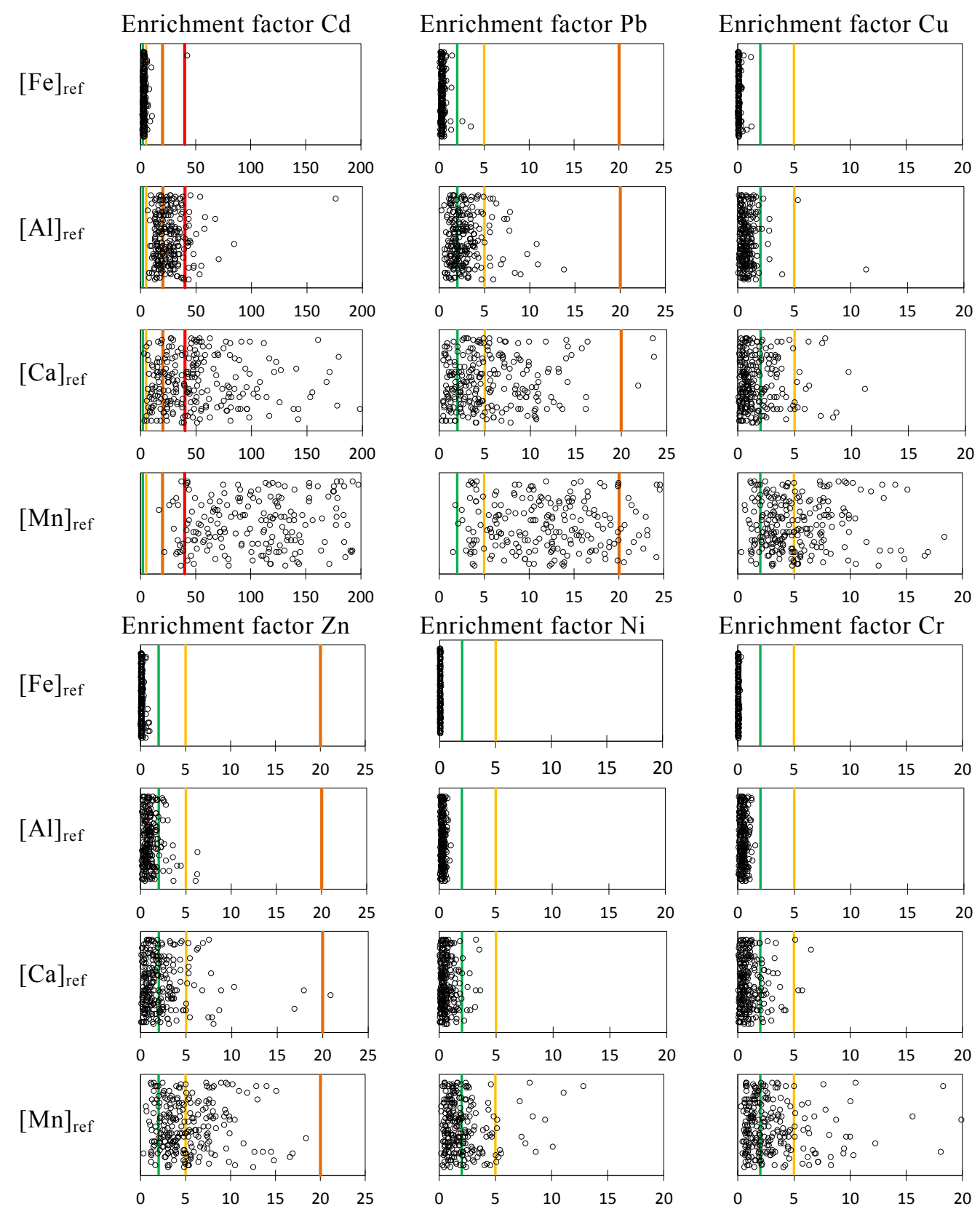

Figure 2. Comparison of enrichment factor for target metals using different notmaliser; green, yellow, orange and red colour lines representing contamination categoresis scale proposed by Loska et al. [9] and Sutherland [8] 
Theoretically, the selection of reference element used in EFs calculation should hardly be affected by weathering processes and should show little variability of occurrence [3]. If different reference elements are selected to calculate EFs, they should all show similar pollution signals regardless of which normalizers were being used. In this study, however, all four sets of EFs calculation (refer Figure 2) bear no relationship to each other.

Figure 2 show EFs values for all metals derived from all four normalizers differ in the range from 1 to 4 -folds. EFs derived from $\mathrm{Ca}$ and $\mathrm{Mn}$ normalizer generally had overestimated amount compared to $\mathrm{Al}$ and $\mathrm{Fe}$. We found that $93 \%$ and $6 \%$ of the Cd samples were classified as extremely high polluted and very high polluted respectively when Mn was used as reference element. These outcomes are very different to the other reference elements, in particular to $\mathrm{Fe}$ normalizer. For Fe reference-EFs, $95 \%$ of $\mathrm{Cd}$ samples were classified as moderate enriched or lower. $\mathrm{Al}$ and $\mathrm{Ca}$ normalizer also produced a wide range of $\mathrm{EFs}$ for $\mathrm{Cd}$ samples and these values ranged between $\mathrm{Fe}$ and $\mathrm{Mn}$ references derived EFs. These discrepancies reflect that EFs do not provide a simple technique to differentiate particular suite of metals was whether of anthropogenic origin or vice versa.

The color contour maps of $\mathrm{Pb}$ concentration and EFs in Figure 3 were created using the inverse distance weighting (IDW) spatial interpolation technique in ESRI ArcMap 9.2. In Figure 3, the Pb hotspots in Kuala Terengganu soils are marked in red colors. The $\mathrm{Pb}$ concentration for Kuala Terengganu soils were also compared to Dutch environmental pollutant reference values, also known as "Dutch target" used in environmental remediation, investigation and cleanup purposes. For Kuala Terengganu, three out of 245 samples had exceeded the Dutch recommendation value of $85 \mathrm{mg} / \mathrm{kg}$. The spatial variations for each metal for Kuala Terengganu soil in this study can be found in Poh [17].

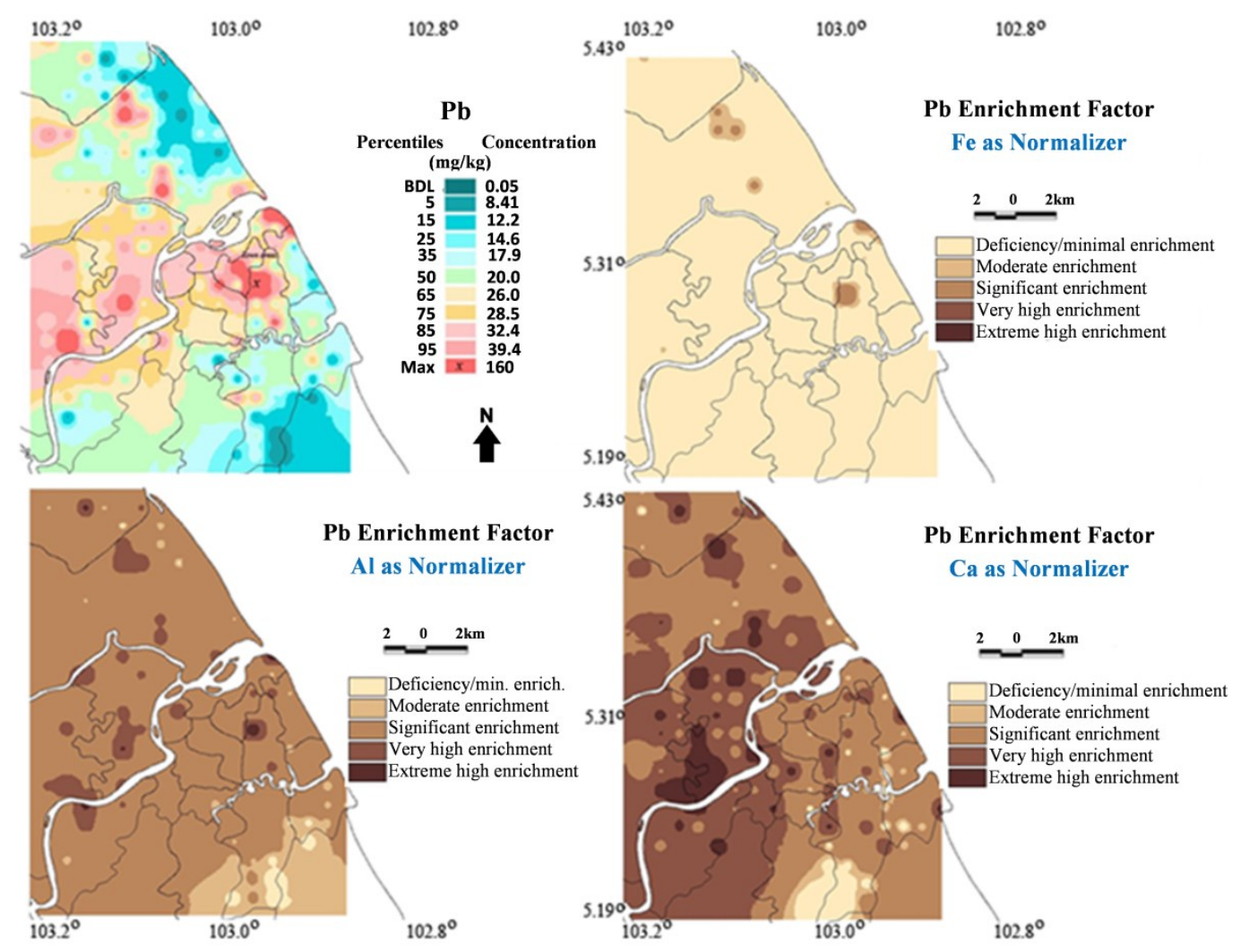

Figure 3. Comparison of the calculated EFs for $\mathrm{Pb}$ in Kuala Terengganu soils 
Three striking features of the EFs pattern of $\mathrm{Pb}$ are evident in Figure 3. First, the EFs for $\mathrm{Pb}$ show great spatial variation compared to $\mathrm{Pb}$ distribution pattern in Kuala Terengganu soil. Second, this variation is multidimensional; that is three different set of reference element show mainly independent of EFs variation. For example, when EFs was calculated relative to the $\mathrm{Pb} / \mathrm{Al}$ ratio, the pattern of high $\mathrm{Pb}$ enrichment was recorded at the same areas in the $\mathrm{Pb}$ concentration map. However, when the $\mathrm{EFs} \mathrm{Pb} / \mathrm{Fe}$ ratio distribution was compared to $\mathrm{Pb}$ concentration map, it turns out, several high enrichment values near the central part of the map disappeared. Furthermore, when $\mathrm{EFs} \mathrm{Pb} / \mathrm{Ca}$ ratio distribution was compared, the high anomaly near to river mouth was no longer present in the map. Meanwhile, an unexpected extremely high EFs had appeared scattered in the central part of the map. Third, these EFs patterns have a pervasive missed-interpretation of pollution signal. In this case, $\mathrm{EFs} \mathrm{Pb} / \mathrm{Al}$ ratio distribution showed $50 \%$ of Kuala Terengganu soils were significantly enriched by $\mathrm{Pb}$ but $\mathrm{EFs} \mathrm{Pb} / \mathrm{Fe}$ ratio distribution, on the other hand illustrated that $99 \%$ of areas were still less contaminated by $\mathrm{Pb}$. The results could overestimate, underestimate, or simply incorrectly estimate the environmental pollution.

The potential sources of errors for EFs technique mentioned above can be explained in a number of ways. First, a huge natural variation in concentration of the different elements in reference materials (i.e. continental crust value, world soil average) exist and using single mean value from a skewed distribution dataset (i.e. Ure and Berrow [5]) does not permit a reasonable EFs assessment. Ure and Berrow [5] reported $\mathrm{Pb}$ concentration in world soil is ranges from $1-888 \mathrm{mg} / \mathrm{kg}$ with average value of $29.2 \mathrm{mg} / \mathrm{kg}$, obviously the given mean value does not reflect the true average $\mathrm{Pb}$ concentration for world average soil. This is one of a very good example to show that using the mean world soil value as a proxy of "natural background values" in enrichment factor inherent a serious flaw to estimate pollution signal in environment.

Second, an inhomogeneous distribution of reference elements in the study area could also lead to misinterpretation in EFs. Overestimation of EFs occurs when the chosen reference elements (normalizer) showed a natural spatial variation that was as large as, or larger than, that of the target metal of interest [4]. In this study, we used quartile coefficient of dispersion (cqv) statistical analysis to compare the dispersion of the maximum concentration differences between $\mathrm{Pb}$ and other reference elements. The calculated cqv for $\mathrm{Ca}, \mathrm{Fe}$ and $\mathrm{Al}$ against $\mathrm{Pb}$ was 2.2, 1.1 and 0.7 respectively, indicated that the natural spatial variation of $\mathrm{Ca}$ was found 2 times greater than $\mathrm{Pb}$. We found that the large dispersion of $\mathrm{Ca}$ concentration has attributed greater EFs value of $\mathrm{Pb}$ in Kuala Terengganu and the $\mathrm{Pb} / \mathrm{Ca}$ ratio $\mathrm{EFs}$ was found greater than $\mathrm{Pb} / \mathrm{Al}$ and $\mathrm{Pb} / \mathrm{Fe}$ ratio $\mathrm{EFs}$ by order of two magnitudes (Figure 3).

The large discrepancies in EFs value could be due to two other factors: (i) the differential solubility of refractory minerals in acid digestion protocols as well as grain size fractionation effect resulted different concentration of metal elements in Earth materials and; (ii) the significance of biogeochemical and weathering processes that control element concentration in Earth surface are not considered in EFs assessment on pollution studies. Reimann and de Caritat $[3,4]$ and Desaules [18] have provide a detailed explanation and references in conceptual shortcomings of EFs in environmental studies.

\section{Conclusion}

Our work demonstrated that application of enrichment factor in the assessment of soil pollution level in Kuala Terengganu inherent a major weakness. One unanticipated finding was that the choice of four commonly-used reference elements ( $\mathrm{Al}, \mathrm{Fe}, \mathrm{Ca}$ and $\mathrm{Mn}$ ) for enrichment calculation could easily alter the enrichment factor values of $\mathrm{Pb}$ by more than 4 -folds although the results were supposed to be similar regardless of which reference elements being used. This bias can be attributed to the absent of a reliable "natural background value" or references. Another shortcoming of EFs approach in assessing the level of anthropogenic sources to environment is EFs did not take into account the natural variation of element concentration in environmental samples in relation to biogeochemical and localized lithogenic processes as mentioned in Reimann and de Caritat [3,4] and Desaules [18]. Therefore, application of enrichment factor as a way to fingerprint the anthropogenic source of heavy metals in soils requires extra caution in future study.

\section{Acknowledgements}

This work was supported by the Universiti Malaysia Terengganu. We especially thank Foo Toon Fong and Mohd Rafie Rosly for assistance with soil sampling. 


\section{References}

1. Dragović, S., N. Mihailović, and B. Gajić (2008). Heavy metals in soils: Distribution, relationship with soil characteristics and radionuclides and multivariate assessment of contamination sources. Chemosphere, 72(3): $491-495$.

2. Luo, X.-S., S. Yu, Y.-G. Zhu, and X.-D. Li (2012). Trace metal contamination in urban soils of China. Science of The Total Environment, 421-422:17 - 30.

3. Reimann, C. and Caritat, P. D. (2000). Intrinsic flaws of element enrichment factors (EFs) in environmental geochemistry. Environmental Science \& Technology, 34(24):5084 - 5091.

4. Reimann, C. and Caritat, P. D. (2005). Distinguishing between natural and anthropogenic sources for elements in the environment: Regional geochemical surveys versus enrichment factors. Science of The Total Environment, 337(1-3): $91-107$.

5. Ure, A. M. and Berrow, M. L. (1982). The elemental constituents of soils, in environmental chemistry: Volume 2, H.J.M. Bowen, Editor. The Royal Society of Chemistry: pp. $94-204$.

6. Biot, Y. Z. and Razak, A. H. (1982). Semi-detailed soil survey report of the Terengganu river basin. Department of Agriculture, Malaysia.

7. Zarcinas, B. A., Ishak, C. F., McLaughlin, M. J. and Cozens, G. (2004). Heavy metals in soils and crops in Southeast Asia. Environmental Geochemistry and Health, 26(4): 343 - 357.

8. Sutherland, A. R. (2000). Bed sediment-associated trace metals in an urban stream, Oahu, Hawaii. Environmental Geology, 39(6): 611 - 627.

9. Loska, K., D. Wiechuła, and Korus, I. (2004). Metal contamination of farming soils affected by industry. Environment International, 30(2): 159 - 165.

10. Bourennane, H., Douay, F., Sterckeman, T., Villanneau, E., Ciesielski, H., King, D. and Baize, D. (2010). Mapping of anthropogenic trace elements inputs in agricultural topsoil from Northern France using enrichment factors. Geoderma, 157(3-4): $165-174$.

11. Chen, H., Teng, Y., Lu, S., Wang, Y. and Wang, J. (2015). Contamination features and health risk of soil heavy metals in China. Science of The Total Environment, 512-513: 143 - 153.

12. Ye, C., Li, S., Zhang, Y. and Zhang, Q. (2011). Assessing soil heavy metal pollution in the water-levelfluctuation zone of the Three Gorges Reservoir, China. Journal of Hazardous Materials, 191(1-3): 366 -372.

13. Schulin, R., Curchod, F., Mondeshka, M., Daskalova, A. and Keller, A. (2007). Heavy metal contamination along a soil transect in the vicinity of the iron smelter of Kremikovtzi (Bulgaria). Geoderma, 140(1-2): 52 - 61 .

14. Qin, F., Ji, H., Li, Q., Guo, X., Tang, L. and Feng, J. (2014). Evaluation of trace elements and identification of pollution sources in particle size fractions of soil from iron ore areas along the Chao River. Journal of Geochemical Exploration, 138: 33 - 49.

15. Krishna, A. K. and Govil, P. K. (2008). Assessment of heavy metal contamination in soils around Manali industrial area, Chennai, Southern India. Environmental Geology, 54(7): 1465 - 1472.

16. Szolnoki, Z., Farsang, A., and Puskás, I. (2013). Cumulative impacts of human activities on urban garden soils: Origin and accumulation of metals. Environmental Pollution, 177: $106-115$.

17. Poh, S. C. (2008). Distribution and source apportionment of elements in urban soil of Kuala Terengganu, Malaysia, Thesis Universiti Malaysia Terengganu, Malaysia.

18. Desaules, A., (2012). Critical evaluation of soil contamination assessment methods for trace metals. Science of The Total Environment, 426: 120 - 131. 